\title{
Analisis dan Desain Struktur Atas Hotel 10 Lantai di Kabupaten Bogor terhadap Beban Gempa
}

\section{(Analysis and Design of the Top Structure of a 10 Floor Hotel in Bogor Regency Against Earthquake Loads)}

\author{
I Wayan Wirya Aristyana ${ }^{1 *}$ dan Muhammad Fauzan ${ }^{1}$ \\ ${ }^{1}$ Departemen Teknik Sipil dan Lingkungan, Fakultas Teknologi Pertanian, Institut Pertanian Bogor. \\ Jl. Raya Dramaga, Kampus IPB Dramaga, PO BOX 220, Bogor, Jawa Barat Indonesia \\ *Penulis Korespondensi : aristyanawirya@gmail.com
}

Diterima : 15 Maret 2021

Disetujui : 21 April 2021

\section{ABSTRACT}

The type of soil at the location of the hotel building is a type of stiff soil. The applications used in this study are ETABS V16.1 and AutoCAD. Based on the PUSKIM website, the $S_{s}$ and $S_{1}$ Bogor City were 0.881 and 0.356, respectively. Based on the results of the analysis of the application ETABS V16.1 obtained fewer reinforcement design results than the existing reinforcement. The maximum nominal moment of the beam is $508.3 \mathrm{kNm}$ while the ultimate moment is $498.4 \mathrm{kNm}$. The maximum nominal shear force of the beam is $565.9 \mathrm{kN}$ while the ultimate shear force is $538.4 \mathrm{kN}$. The maximum nominal moment of the column is $1488.5 \mathrm{kNm}$ while the maximum ultimate moment is $1478 \mathrm{kNm}$. The maximum nominal axial force of the column is $6291 \mathrm{kN}$ while the maximum ultimate axial force is $6287 \mathrm{kN}$. The maximum nominal bending moment of the floor plate is $41.3 \mathrm{kNm}$ while the maximum ultimate moment is $39.9 \mathrm{kNm}$. The maximum nominal shear force of the floor plate is $234.7 \mathrm{kN}$ while the maximum ultimate shear force is $228.9 \mathrm{kN}$. The nominal shear force of shear wall is $8238.5 \mathrm{kN}$ while the ultimate shear force is $8194.7 \mathrm{kN}$. Based on the internal forces, the building that has been built is in accordance with the plan so that it is safe to withstand earthquake loads.

Keywords: Bogor, Earthquake, ETABS V16.1, Hotel.

\section{PENDAHULUAN}

Indonesia telah memasuki era pembangunan dimana setiap daerah di Indonesia harus memperhatikan pembangunan. Pembangunan yang dimaksud disini adalah pembangunan dari sektor infrastruktur. Infrastruktur yang dibangun di Indonesia telah meningkat dari tahun ke tahun. Infrastruktur yang dibangun seperti perkantoran, mall, sekolah, perumahan, hotel dan yang lainnya. Pembangunan yang dilakukan tersebut memerlukan ketersediaan lahan yang cukup, namun pembangunan saat ini berorientasi ke arah vertikal dengan cara dibuat bertingkat untuk meminimalisir penggunaan lahan. Bangunan bertingkat dibangun untuk mengatasi kepadatan lahan yang dari tahun ke tahun semakin berkurang (Egan \& Leo, 2018).

Pembebanan struktur gedung mengacu pada "Standar Pembebanan Untuk Bangunan Gedung" dalam SNI 03-2847-2019 dengan tambahan peraturan mengenai beban gempa yang tertuang dalam "Standar Perencanaan Ketahanan Gempa Untuk Struktur Bangunan Gedung" dalam SNI 03-17262019. Beban gempa merupakan beban yang sangat diperhitungkan dalam mendesain suatu gedung. Beban gempa memiliki nilai periode tertentu sehingga struktur dapat bergoyang-goyang secara berulang-ulang. Kejadian tersebut apabila berlangsung dalam periode yang lama, akan menyebabkan struktur 
bangunan tersebut runtuh. Persebaran wilayah gempa dapat dilihat pada Peta Zonasi Gempa Indonesia 2017, dimana peta tersebut selalu mengalami perubahan dari tahun ke tahun yang disebabkan karena pergerakan batuan dasar bumi. Pada peta ini, telah dicantumkan sesar-sesar aktif di daratan serta pertemuan antar lempeng tektonik (Ismail, 2014).

Perencanaan gedung bertingkat harus memperhatikan beberapa kriteria, seperti kriteria kekuatan, kriteria perilaku yang baik terhadap gempa serta kriteria ekonomis (Jasman, 2015). Mendesain dan merencanakan suatu bangunan bertingkat diperlukan ketelitian yang sangat tinggi serta waktu yang relatif lama. Oleh karena itu sebagian besar konsultan maupun pelaksana pembangunan (kontraktor) menggunakan bantuan aplikasi teknik dalam merencanakan, mendesain dan membuat laporan struktur suatu proyek. Aplikasi yang sudah sangat umum digunakan di Indonesia adalah AutoCAD yang digunakan untuk membuat gambar dua dimensi maupun tiga dimensi, serta dibantu aplikasi lainnya seperti SAP2000 atau ETABS untuk menganalisa kekuatan strukturnya (Fajar Meidiansyah et al., 2014).

\section{METODOLOGI}

Penelitian dilakukan pada bulan Maret hingga Agustus 2020. Pelaksanaan penelitian menggunakan data sekunder. Data sekunder merupakan data yang diperoleh dari pemilik gedung hotel tersebut. Data sekunder yang digunakan yaitu data gambar as built drawing, data tanah gedung hotel, serta data fungsi hotel. Gambar as built drawing menampilkan detail gedung yang telah dibangun di hotel tersebut. Selain itu, data sekunder pendukung lainnya seperti hasil penelitian terdahulu, studi pustaka, peta, laporan, jurnal, skripsi, dan dokumen yang ada di berbagai instansi perusahaan.

Peralatan yang digunakan pada penelitian ini adalah telepon genggam yang dilengkapi dengan aplikasi google map, laptop yang dilengkapi dengan aplikasi ETABS V16.1, AutoCAD, dan Microsoft Office. Langkah awal dari penelitian ini adalah studi pustaka terkait analisis dan desain struktur atas suatu gedung hotel. Studi lapangan dilakukan di lokasi penelitian. Penelitian dilanjutkan dengan pengolahan data sekunder yang diperoleh dari berbagai sumber. Data sekunder yang telah didapatkan, selanjutnya diolah, dianalisis dan dilakukan desain terhadap gedung tersebut.

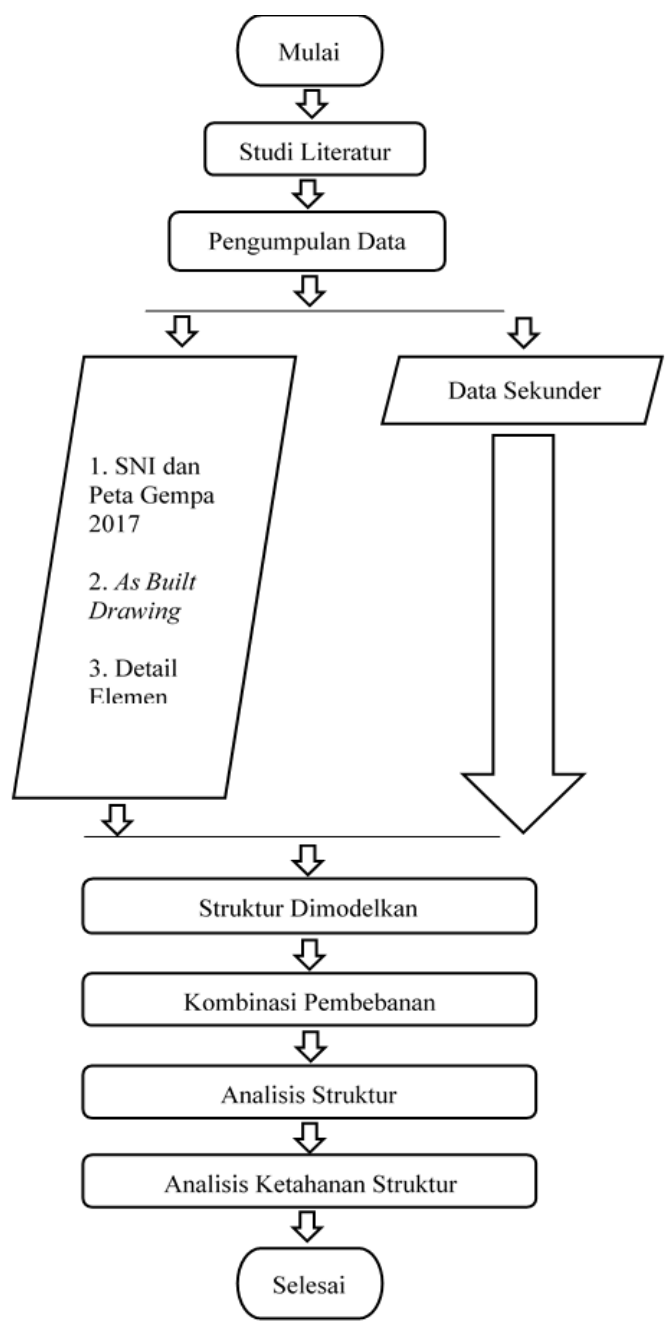

Gambar 1. Diagram Alir Penelitian 


\section{HASIL DAN PEMBAHASAN}

\section{Keadaan Umum Lokasi}

Kabupaten Bogor merupakan salah satu kabupaten besar yang ada di Indonesia. Infrastruktur yang terdapat di Kabupaten Bogor seperti tempat ibadah, rumah sakit, puskesmas, fasilitas pendidikan dan salah satunya adalah hotel. Semua infrastruktur tersebut digunakan untuk kepentingan masyarakat sehingga dapat meningkatkan perekonomian masyarakat Kabupaten Bogor. Penelitian ini dilakukan untuk menganalisis ketahanan gedung hotel yang ada di Kabupaten Bogor terhadap beban gempa. Luas dari hotel tersebut \pm 2338 $\mathrm{m}^{2}$ dengan tinggi hotel tersebut $33 \mathrm{~m}$ dan terdapat \pm 120 kamar. Banyak fasilitas yang terdapat di hotel tersebut, seperti restoran, kolam renang, aula, ruang rapat dan yang lainnya. Hotel ini memiliki tempat parkir setinggi $8.25 \mathrm{~m}$ dimana material konstruksi yang menyusun tempat parkir tersebut adalah baja.

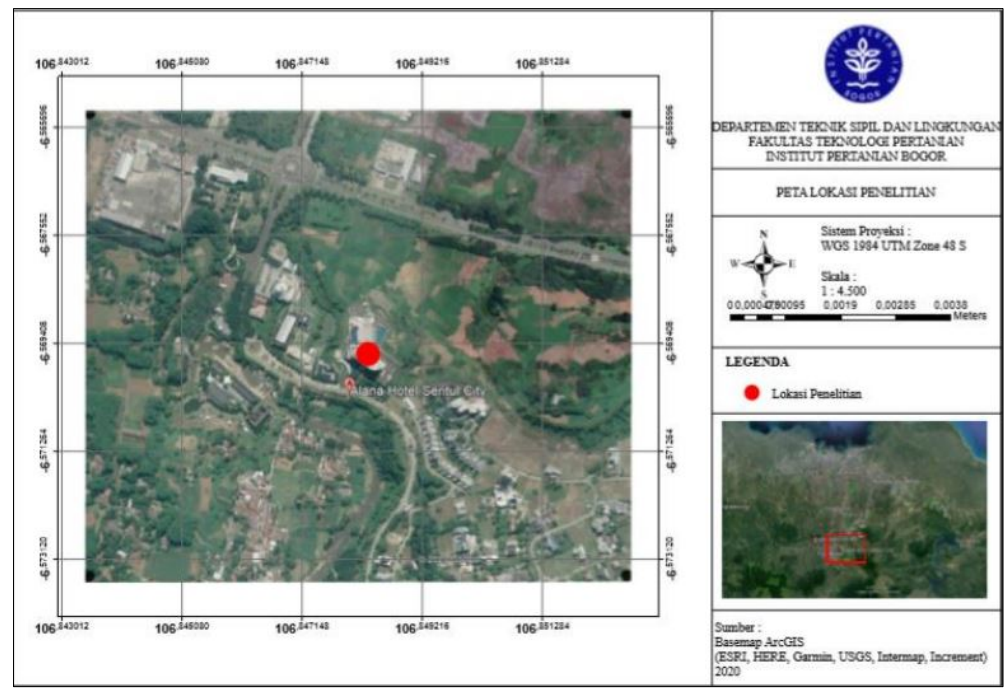

Gambar 2. Lokasi Hotel

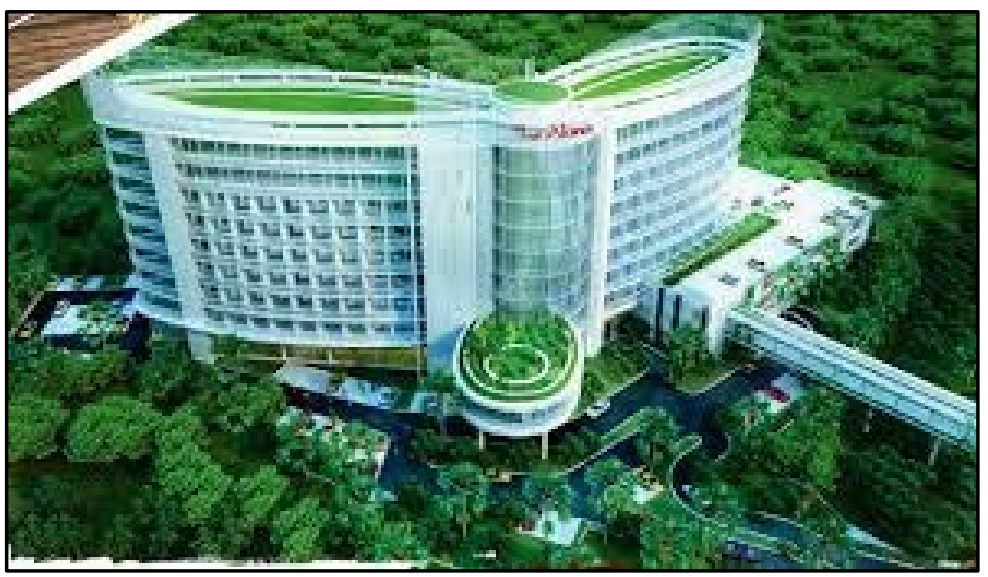

Gambar 3. Tampak Gedung Hotel 


\section{Spektrum Gempa}

Spektrum gempa dibuat berdasarkan Peta Gempa Indonesia 2017. Pembuatan spektrum gempa memperhatikan 2 faktor yaitu letak astronomis serta jenis tanah dari gedung hotel tersebut. Gedung hotel tersebut terletak pada koordinat $6^{\circ} 34^{\prime} 55^{\prime}$ ' LS serta $106^{\circ} 50^{\prime} 55^{\prime}$ ' BT serta jenis tanah di lokasi pembangunan gedung hotel itu yaitu jenis tanah sedang (D), sehingga dari 2 faktor tersebut dapat dicari besarnya percepatan batuan dasar. Terdapat 2 jenis percepatan batuan dasar yaitu percepatan batuan dasar saat $\mathrm{T}=0.2$ $\mathrm{s}\left(\mathrm{S}_{\mathrm{s}}\right)$ dan percepatan batuan dasar saat $\mathrm{T}=1 \mathrm{~s}\left(\mathrm{~S}_{1}\right)$.

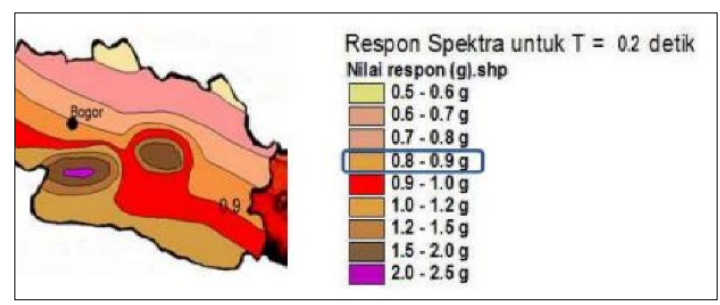

Gambar 4. Percepatan Batuan Dasar saat $\mathrm{T}=0.2 \mathrm{~s}$

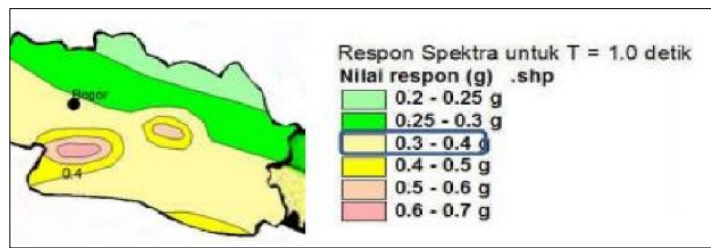

Gambar 5. Percepatan Batuan Dasar saat $\mathrm{T}=1 \mathrm{~s}$

Nilai $S_{s}$ dan $S_{1}$ dapat juga diperoleh dengan menggunakan situs Pusat Penelitian dan Pengembangan Pemukiman (PUSKIM) Kementrian Pekerjaan Umum dan Perumahan Rakyat. Hasil analisa dari situs PUSKIM untuk lokasi penelitian di Kabupaten Bogor dengan jenis tanah sedang (D), diperoleh nilai $\mathrm{S}_{\mathrm{s}}$ sebesar 0.881 serta nilai $\mathrm{S}_{1}$ sebesar 0.356. Nilai $\mathrm{S}_{\mathrm{s}}$ dan $\mathrm{S}_{1}$ yang diperoleh dari situs PUSKIM berada dalam rentang yang terdapat pada Peta Gempa Indonesia 2017. Nilai $S_{s}$ dijadikan acuan dalam menentukan nilai faktor amplifikasi getaran periode $0.2 \mathrm{~s}$ $\left(F_{a}\right)$ dan nilai $S_{1}$ dijadikan acuan dalam menentukan nilai faktor amplifikasi periode $1 \mathrm{~s}\left(\mathrm{~F}_{\mathrm{v}}\right)$.

Berdasarkan situs PUSKIM, nilai $F_{a}$ dan $F_{v}$ diperoleh sebesar 1.155 dan 1.703. Selain itu, didapatkan pula nilai percepatan pada periode pendek ( $\mathrm{S}_{\mathrm{MS}}$ ) sebesar 0.996, spektrum respon percepatan pada periode 1 detik ( $\left.\mathrm{S}_{\mathrm{M} 1}\right)$ sebesar 0.594, percepatan spektral desain untuk periode pendek (SDS) sebesar 0.664 dan pada periode $1 \mathrm{~s}\left(\mathrm{~S}_{\mathrm{D} 1}\right)$ sebesar 0.396 .

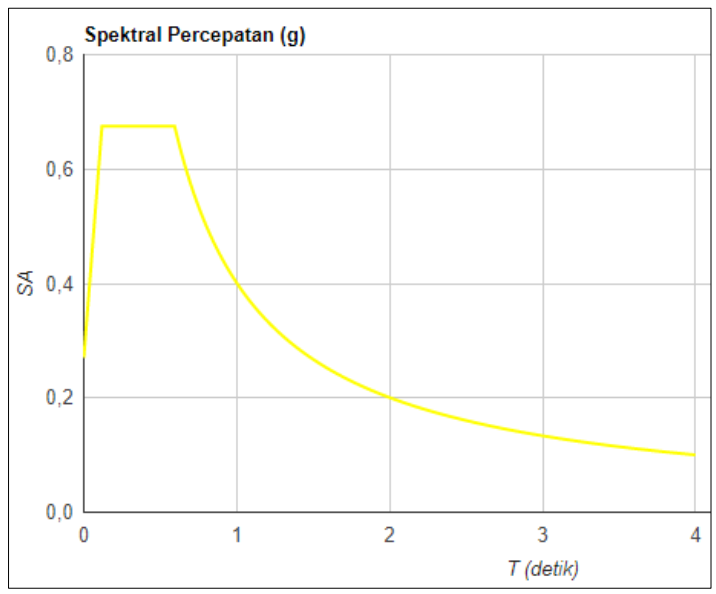

Gambar 6. Grafik Desain Spektrum Gempa Hotel

\section{Pemodelan Struktur}

Komponen utama struktur atas sebuah gedung hotel terdiri dari balok, kolom dan plat lantai. Ketiga komponen tersebut dimodelkan pada aplikasi ETABS V16.1 sesuai dengan gambar as built drawing yang telah diberikan. Pemodelan struktur dilakukan secara 3 dimensi, baik pada sumbu-x, sumbu-y dan sumbu-z. Material yang digunakan pada pembangunan gedung hotel ini menggunakan beton bertulang, dimana kolom menggunakan mutu K-28 $\mathrm{MPa}$, balok dan plat lantai menggunakan beton 
mutu K-24 MPa. Mutu baja yang digunakan untuk tulangan beton yaitu mutu $400 \mathrm{MPa}$ dimana mutu baja 400 MPa memiliki makna bahwa kuat luluh baja tersebut sebesar $400 \mathrm{MPa}$. Struktur pondasi yang digunakan dimodelkan sebagai tumpuan jepit dan menggunakan jenis pondasi bored pile.

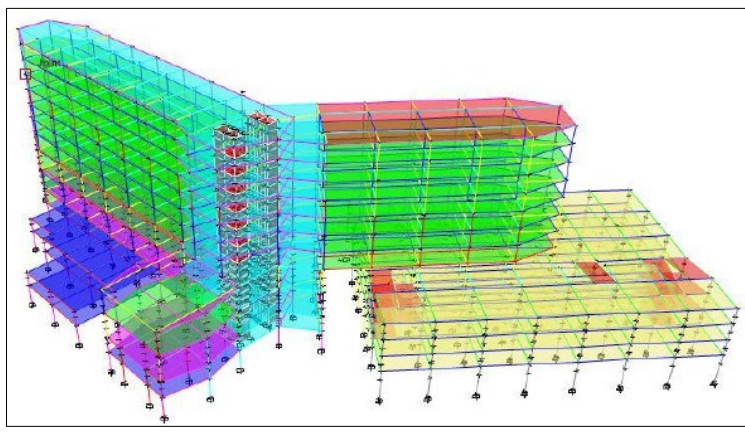

Gambar 7. Pemodelan 3 Dimensi Gedung Hotel

Pemberian beban dilakukan
setelah gedung hotel tersebut dimodelkan. Pembebanan gedung mengacu pada SNI 03-1727-2013, dimana beban yang diberikan dibedakan menjadi 2 jenis, yaitu beban statis dan beban dinamis. Beban statis dibagi menjadi 2 lagi yaitu beban mati dan beban hidup, sedangkan beban dinamis dibedakan menjadi 2 yaitu beban angin dan beban gempa.

\begin{tabular}{lr} 
Tabel 1. Beban Mati Tambahan Gedung \\
\hline Jenis Bahan & Berat $(\mathrm{kg} / \mathrm{m} 2)$ \\
\hline Dinding Pasangat $1 / 2$ Bata & 250 \\
Langit langit + Penggantung & 18 \\
Lantai Keramik & 24 \\
Spesi per cm tebal & 21 \\
Mekanik Elektrikal & 25 \\
Waterproof & 50 \\
\hline
\end{tabular}

Tabel 2. Beban Hidup Gedung

\begin{tabular}{lr} 
Jenis Beban & Berat $(\mathrm{kg} / \mathrm{m} 2)$ \\
\hline Lantai Parkir & 400 \\
Lantai hotel & 200 \\
Lantai Atap Hotel & 200 \\
Lantai Ballroom & 400 \\
Lantai Atap Kebun & 100 \\
\hline
\end{tabular}

\section{Pembenanan Gempa}

Metode pembebanan gempa dibedakan menjadi 2 jenis, yaitu metode statik dan metode dinamik. Metode dinamik pun dibedakan menjadi 2 jenis, yaitu metode respon spektrum dan metode time history. Pada penelitian ini digunakan jenis pembebanan statik ekivalen. Metode ini sangat cocok digunakan untuk gedung yang sifatnya beraturan. Berdasarkan SNI 03-17262019, gedung hotel memiliki jenis pemanfaatan yang hampir serupa dengan gedung apartemen/rumah susun sehingga tergolong ke dalam kategori resiko II dimana untuk gedung dengan kategori resiko II memiliki faktor keutamaan gedung sebesar 1.0.

Tabel 3. Kategori Resiko Gedung

\begin{tabular}{lc}
\multicolumn{1}{c}{ Jenis Pemanfaatan } & $\begin{array}{c}\text { Kategori } \\
\text { Resiko }\end{array}$ \\
\hline Gedung dan non gedung yang memiliki resiko rendah, seperti : & \\
Fasilitas pertanian, perkebunan & I \\
Fasilitas sementara & \\
$\quad$ Gudang penyimpanan & \\
\hline Semua gedung dan struktur lain namun tidak dibatasi untuk: & II \\
$\quad$ Perumahan & \\
Rumah toko dan rumah kantor & \\
Gedung perkantoran & \\
Gedung apartemen/hotel & \\
\hline
\end{tabular}


Tabel 4. Faktor Keutamaan Gempa

\begin{tabular}{cc} 
Kategori Resiko & Faktor Keutamaan Gempa (I) \\
\hline I atau II & 1.0 \\
III & 1.25 \\
IV & 1.50 \\
\hline
\end{tabular}

Hal lain yang perlu diperhitungkan dalam mendesain gedung tahan gempa adalah sistem pemikul gayanya. Berdasarkan SNI 03-1726-2019, sistem pemikul gaya yang digunakan pada gedung hotel ini adalah rangka beton bertulang pemikul momen khusus, yang dikarenakan gedung hotel ini berbahan material beton bertulang dan gedung hotel ini memiliki fungsi yang khusus dan harus sangat kuat dalam menahan beban gempa yang ada. Berdasarkan hal tersebut, diperoleh koefisien modifikasi respons $\left(\mathrm{R}^{\mathrm{a}}\right)$ sebesar 8 , faktor kuat lebih sistem $\left(\Omega_{0}{ }^{b}\right)$ sebesar 3 dan faktor pembesaran defleksi $\left(\mathrm{C}_{\mathrm{d}}{ }^{\mathrm{c}}\right)$ sebesar 5.5. Nilai-nilai tersebut dimasukkan ke dalam persamaan sehingga diperoleh nilai beban nominal statik ekivalen. Pada metode pembebanan gempa, digunakan beberapa kombinasi pembebanan. Kombinasi pembebanan yang digunakan berdasarkan SNI 03-2847-2019.

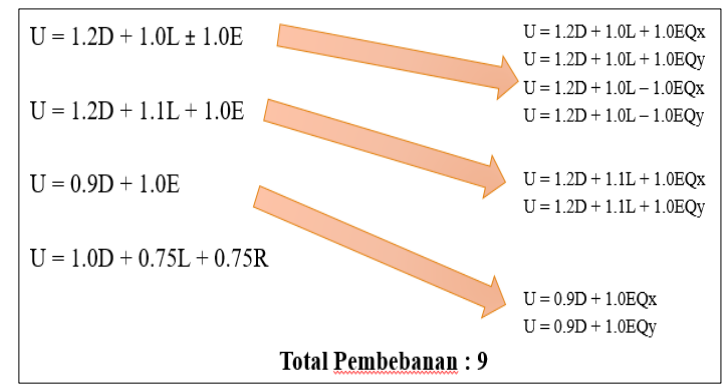

Gambar 8. Kombinasi Pembebanan Gedung

\section{Evaluasi Struktur Kolom}

Kolom adalah batang tekan vertikal dari elemen struktur yang memikul beban aksial dari balok dan lantai. Kolom merupakan elemen struktur tekan yang memiliki fungsi sangat penting dalam suatu gedung sehingga keruntuhan pada suatu kolom merupakan lokasi kritis yang dapat menyebabkan keruntuhan total. Kolom yang digunakan pada konstruksi hotel ini berbentuk persegi dan persegi panjang. Hasil analisis aplikasi ETABS V16.1 menunjukkan bahwa semua elemen kolom gedung ini adalah aman, yang ditandai dengan tidak adanya kolom yang berwarna merah (overstress). Hasil analisis tulangan lentur dan tulangan geser pada aplikasi ETABS menunjukkan jumlah tulangan hasil desain lebih besar dibandingkan dengan eksistingnya. Gaya dalam yang ditinjau pada kolom yaitu gaya aksial dan momen. Berdasarkan hasil analisis didapatkan gaya aksial dan momen nominal lebih besar dibandingkan dengan gaya aksial dan momen ultimit dimana menandakan bahwa gaya dalam sudah memenuhi ketentuan dalam perencanaan. 
Tabel 5. Perbandingan Tulangan Hasil Desain dan Eksisting Kolom

\begin{tabular}{|c|c|c|c|c|c|}
\hline Kolom & Dimensi & Kondisi & Tul. Lentur & Tul. Geser & Ket \\
\hline \multirow[t]{2}{*}{ C3.3 } & $800 \times 700$ & Desain & $18 \mathrm{D} 19$ & D $10-100$ & Aman \\
\hline & & Eksisting & $20 \mathrm{D} 19$ & D $10-100$ & \\
\hline \multirow[t]{2}{*}{$\mathrm{C} 3.4$} & $1000 \times 300$ & Desain & $18 \mathrm{D} 19$ & D $10-150$ & Aman \\
\hline & & Eksisting & $20 \mathrm{D} 19$ & D $10-150$ & \\
\hline \multirow[t]{2}{*}{ C 3.5} & $1000 \times 300$ & Desain & $18 \mathrm{D} 19$ & D $10-150$ & Aman \\
\hline & & Eksisting & $20 \mathrm{D} 19$ & D $10-150$ & \\
\hline \multirow[t]{2}{*}{$\mathrm{C} 3.6$} & $1000 \times 300$ & Desain & $18 \mathrm{D} 19$ & D $10-150$ & Aman \\
\hline & & Eksisting & $20 \mathrm{D} 19$ & D $10-150$ & \\
\hline \multirow[t]{2}{*}{$\mathrm{C} 3.7$} & $900 \times 300$ & Desain & $18 \mathrm{D} 19$ & D $10-150 / 200$ & Aman \\
\hline & & Eksisting & $20 \mathrm{D} 19$ & D $10-150 / 200$ & \\
\hline \multirow[t]{2}{*}{$\mathrm{C} 3.8$} & $700 \times 300$ & Desain & $16 \mathrm{D} 16$ & D $10-150 / 200$ & Aman \\
\hline & & Eksisting & $20 \mathrm{D} 16$ & D $10-150 / 200$ & \\
\hline \multirow[t]{2}{*}{ C 3.9} & $700 \times 300$ & Desain & $18 \mathrm{D} 16$ & D $10-150 / 200$ & Aman \\
\hline & & Eksisting & $20 \mathrm{D} 16$ & D $10-150 / 200$ & \\
\hline \multirow[t]{2}{*}{$\mathrm{C} 3.10$} & $700 \times 300$ & Desain & $18 \mathrm{D} 16$ & D $10-150 / 200$ & Aman \\
\hline & & Eksisting & $20 \mathrm{D} 16$ & D $10-150 / 200$ & \\
\hline \multirow[t]{2}{*}{ C3'.3 } & $800 \times 700$ & Desain & $18 \mathrm{D} 19$ & D $10-150$ & Aman \\
\hline & & Eksisting & $20 \mathrm{D} 19$ & D $10-100$ & \\
\hline \multirow[t]{2}{*}{$\mathrm{C} 3{ }^{\prime} .4$} & $1000 \times 300$ & Desain & $18 \mathrm{D} 19$ & D $10-200$ & Aman \\
\hline & & Eksisting & $20 \mathrm{D} 19$ & D $10-150$ & \\
\hline
\end{tabular}

Tabel 6. Gaya Dalam pada Kolom

\begin{tabular}{cccccc}
\hline \multirow{2}{*}{ Kolom } & \multirow{2}{*}{ Dimensi } & \multicolumn{2}{c}{ Gaya Aksial $(\mathrm{kN})$} & \multicolumn{2}{c}{ Momen $(\mathrm{kNm})$} \\
& & Nominal & Ultimit & Nominal & Ultimit \\
\hline C3.3 & $800 \times 700$ & 6291 & 6287 & 1488 & 1478 \\
C3.4 & $1000 \times 300$ & 673 & 665 & 414 & 403 \\
C3.5 & $1000 \times 300$ & 673 & 656 & 414 & 410 \\
C3.6 & $1000 \times 300$ & 673 & 666 & 414 & 399 \\
C3.7 & $900 \times 300$ & 673 & 602 & 414 & 350 \\
C3.8 & $700 \times 300$ & 281 & 271 & 236 & 223 \\
C3.9 & $700 \times 300$ & 281 & 265 & 236 & 209 \\
C3.10 & $700 \times 300$ & 281 & 278 & 236 & 221 \\
C3'.3 & $800 \times 700$ & 6291 & 6190 & 1488 & 1278 \\
C3'.4 & $1000 \times 300$ & 673 & 669 & 414 & 401 \\
\hline
\end{tabular}

\section{Evaluasi Struktur Balok}

Balok adalah elemen struktur yang berfungsi untuk menahan beban lantai. Balok juga berfungsi sebagai rangka pengikat bangunan secara horizontal. Semakin besar momen yang bekerja pada balok maka kebutuhan tulangan yang dibutuhkan pun semakin banyak. Tulangan lentur yang didesain dalam 2 kondisi, yaitu pada kondisi lapangan dan kondisi tumpuan. Berdasarkan hasil analisis aplikasi ETABS V16.1 menunjukkan bahwa balok hotel tersebut mampu untuk menahan beban yang ada, yang ditandai dengan tidak adanya balok yang berwarna merah (overstress).

Hasil analisis momen yang diperoleh dari aplikasi ETABS V16.1 menunjukkan bahwa jumlah tulangan kondisi eksisting berbeda dengan tulangan lentur hasil desain. Tulangan lentur pada kondisi eksisting lebih banyak dibandingan dengan kondisi desain, yang menunjukkan bahwa tulangan yang digunakan pada balok 
JSIL | Aristyana dan Fauzan : Analisis dan Desain Struktur Atas Hotel ID Lantai terhadap Beban Gempa

bersifat boros. Jumlah dan jarak tulangan geser yang digunakan pada kondisi eksisting dengan hasil desain tidak berbeda jauh, yang artinya tulangan geser pada kondisi eksisting telah memenuhi kebutuhan tulangan geser hasil perencanaan. Gaya dalam yang ditinjau pada balok adalah momen dan gaya gesernya. Berdasarkan hasil analisis aplikasi ETABS V16.1 diperoleh momen dan gaya geser nominal lebih besar dibandingkan dengan momen dan gaya geser ultimitnya, yang menandakan bahwa gaya dalam yang menyusun balok telah sesuai dengan perencanaan yang ada.

Tabel 7. Perbandingan Tulangan Hasil Desain dan Eksisting Balok

\begin{tabular}{|c|c|c|c|c|c|c|c|c|c|}
\hline \multirow[t]{3}{*}{ Balok } & \multirow[t]{3}{*}{ Dimensi } & \multirow[t]{3}{*}{ Kondisi } & \multicolumn{4}{|c|}{ Lentur } & \multicolumn{2}{|c|}{ Geser } & \multirow[t]{3}{*}{ Ket } \\
\hline & & & \multicolumn{2}{|c|}{ Tumpuan } & \multicolumn{2}{|c|}{ Lapangan } & \multirow[t]{2}{*}{ Tumpuan } & \multirow[t]{2}{*}{ Lapangan } & \\
\hline & & & Atas & Bawah & Atas & Bawah & & & \\
\hline \multirow[t]{2}{*}{ T6 } & $200 \times 450$ & Desain & $5 \mathrm{D} 13$ & $5 \mathrm{D} 13$ & 2 D 13 & $2 \mathrm{D} 13$ & D $10-175$ & D $10-250$ & Aman \\
\hline & & Eksisting & $6 \mathrm{D} 13$ & $6 \mathrm{D} 13$ & $3 \mathrm{D} 13$ & $3 \mathrm{D} 13$ & D $10-175$ & D $10-250$ & \\
\hline \multirow[t]{2}{*}{ T7 } & $250 \times 500$ & Desain & $4 \mathrm{D} 16$ & 4 D 16 & $3 \mathrm{D} 16$ & $3 \mathrm{D} 16$ & D $10-100$ & D $10-100$ & Aman \\
\hline & & Eksisting & $4 \mathrm{D} 16$ & 4D 16 & $4 \mathrm{D} 16$ & $4 \mathrm{D} 16$ & D $10-100$ & D $10-150$ & \\
\hline \multirow[t]{2}{*}{ T8 } & $250 \times 550$ & Desain & $6 \mathrm{D} 16$ & $6 \mathrm{D} 16$ & $2 \mathrm{D} 16$ & $2 \mathrm{D} 16$ & D $10-150$ & D $10-200$ & Aman \\
\hline & & Eksisting & $6 \mathrm{D} 16$ & $6 \mathrm{D} 16$ & $3 \mathrm{D} 16$ & $3 \mathrm{D} 16$ & D $10-150$ & D $10-200$ & \\
\hline \multirow[t]{2}{*}{ T9 } & $300 \times 600$ & Desain & $6 \mathrm{D} 16$ & $6 \mathrm{D} 16$ & $4 \mathrm{D} 16$ & $4 \mathrm{D} 16$ & D $10-125$ & D $10-125$ & Aman \\
\hline & & Eksisting & $7 \mathrm{D} 16$ & $7 \mathrm{D} 16$ & $4 \mathrm{D} 16$ & $4 \mathrm{D} 16$ & D $10-125$ & D $10-200$ & \\
\hline \multirow[t]{2}{*}{$\mathrm{T} 10$} & $300 \times 650$ & Desain & $7 \mathrm{D} 16$ & 7 D 16 & $3 \mathrm{D} 16$ & $3 \mathrm{D} 16$ & D $10-150$ & D $10-200$ & Aman \\
\hline & & Eksisting & $8 \mathrm{D} 16$ & $8 \mathrm{D} 16$ & 4D 16 & $4 \mathrm{D} 16$ & D $10-125$ & D $10-200$ & \\
\hline \multirow[t]{2}{*}{ T11 } & $350 \times 700$ & Desain & $6 \mathrm{D} 19$ & $6 \mathrm{D} 19$ & $3 \mathrm{D} 19$ & 3 D 19 & D $10-125$ & D $10-200$ & Aman \\
\hline & & Eksisting & $7 \mathrm{D} 19$ & $7 \mathrm{D} 19$ & $4 \mathrm{D} 19$ & $4 \mathrm{D} 19$ & D $10-100$ & D $10-200$ & \\
\hline \multirow[t]{2}{*}{$\mathrm{T} 12$} & $350 \times 750$ & Desain & 7 D 19 & $7 \mathrm{D} 19$ & $3 \mathrm{D} 19$ & $3 \mathrm{D} 19$ & D $10-100$ & D $10-200$ & Aman \\
\hline & & Eksisting & $8 \mathrm{D} 19$ & $8 \mathrm{D} 19$ & $4 \mathrm{D} 19$ & $4 \mathrm{D} 19$ & D $10-100$ & D $10-200$ & \\
\hline \multirow[t]{2}{*}{ P4 } & $200 \times 350$ & Desain & $3 \mathrm{D} 13$ & $2 \mathrm{D} 13$ & $2 \mathrm{D} 13$ & $3 \mathrm{D} 13$ & D $8-100$ & D $8-175$ & Aman \\
\hline & & Eksisting & $4 \mathrm{D} 13$ & $2 \mathrm{D} 13$ & $2 \mathrm{D} 13$ & $4 \mathrm{D} 13$ & D $8-75$ & D $8-150$ & \\
\hline \multirow[t]{2}{*}{ P5 } & $200 \times 400$ & Desain & $4 \mathrm{D} 13$ & $3 \mathrm{D} 13$ & $2 \mathrm{D} 13$ & $4 \mathrm{D} 13$ & D $10-175$ & D $10-250$ & Aman \\
\hline & & Eksisting & $5 \mathrm{D} 13$ & $3 \mathrm{D} 13$ & $2 \mathrm{D} 13$ & $5 \mathrm{D} 13$ & D $10-175$ & D $10-250$ & \\
\hline \multirow[t]{2}{*}{ P6 } & $200 \times 450$ & Desain & $4 \mathrm{D} 13$ & $3 \mathrm{D} 13$ & $3 \mathrm{D} 13$ & $4 \mathrm{D} 13$ & D $10-175$ & D $10-250$ & Aman \\
\hline & & Eksisting & $6 \mathrm{D} 13$ & $3 \mathrm{D} 13$ & $3 \mathrm{D} 13$ & $6 \mathrm{D} 13$ & D $10-175$ & D $10-250$ & \\
\hline
\end{tabular}

Tabel 8. Gaya Dalam pada Balok

\begin{tabular}{cccccc}
\hline \multirow{2}{*}{ Balok } & \multirow{2}{*}{ Dimensi } & \multicolumn{2}{c}{ Momen $(\mathrm{kNm})$} & \multicolumn{2}{c}{ Gaya Geser $(\mathrm{kN})$} \\
& & Nominal & Ultimit & Nominal & Ultimit \\
\hline T6 & $200 \times 450$ & 107 & 100.4 & 181.1 & 174.9 \\
T7 & $250 \times 500$ & 118.6 & 109.5 & 346.5 & 321.8 \\
T8 & $250 \times 550$ & 186.8 & 178.8 & 271 & 258.7 \\
T9 & $300 \times 600$ & 242.9 & 239.4 & 359.7 & 338.8 \\
T10 & $300 \times 650$ & 290.7 & 280.5 & 394.2 & 382.7 \\
T11 & $350 \times 700$ & 410 & 401.9 & 523.6 & 510.5 \\
T12 & $350 \times 750$ & 508.3 & 498.4 & 565.9 & 538.4 \\
P4 & $200 \times 350$ & 46.3 & 33.6 & 182.7 & 169.8 \\
P5 & $200 \times 400$ & 69.2 & 65.7 & 156.9 & 138.7 \\
P6 & $200 \times 450$ & 96.3 & 84.7 & 181.1 & 170.7 \\
\hline
\end{tabular}




\section{Evaluasi Struktur Plat Lantai}

Plat adalah elemen struktur yang berfungsi sebagai tempat berpijak saat melakukan aktivitas dalam suatu gedung. Plat lantai memiliki beban hidup, beban mati serta beban mati tambahan. Plat lantai memiliki ketebalan tertentu untuk menahan beban aksial serta momen lentur yang ada. Besarnya tebal plat dan diameter tulangan yang digunakan pada plat sangat berpengaruh pada besarnya momen yang dihasilkan oleh plat. Berdasarkan hasil analisis aplikasi ETABS V16.1, plat lantai aman dalam menahan beban yang ada yang ditandai dengan tidak adanya warna merah (overstress).

Gedung hotel ini terdiri dari 10 lantai dimana setiap lantai memiliki jenis plat yang sedikit berbeda. Lantai 1 memiliki ketebalan $250 \mathrm{~mm}$, lantai 2 dan 3 memiliki ketebalan $150 \mathrm{~mm}$, serta lantai 4 sampai atap memiliki ketebalan $130 \mathrm{~mm}$. Jenis tulangan yang digunakan pada plat lantai sama yaitu tulangan D10-150 mm. Momen ultimit merupakan momen yang dihasilkan oleh aplikasi ETABS sedangkan momen nominal merupakan momen yang dihasilkan dari perhitungan manual. Berdasarkan hasil analisis, momen nominal plat lebih besar dibandingkan dengan momen ultimit yang menandakan bahwa plat telah sesuai dengan ketentuan perencanaan sebelumnya sehingga aman dalam menahan beban yang ada.

Tabel 9. Perbandingan Gaya Dalam Ultimit dan Nominal Plat Lantai

\begin{tabular}{ccccc}
\hline \multirow{2}{*}{ Lantai ke- } & \multicolumn{2}{c}{ Momen Lentur } & \multicolumn{2}{c}{ Gaya Geser } \\
& Nominal $(\mathrm{kNm})$ & Ultimit $(\mathrm{kNm})$ & Nominal $(\mathrm{kN})$ & Ultimit $(\mathrm{kN})$ \\
\hline 1 & 41.3 & 39.9 & 234.7 & 228.9 \\
2 & 22.5 & 20.4 & 130.4 & 128.5 \\
3 & 22.5 & 19.4 & 130.4 & 120.5 \\
4 & 18.8 & 17.2 & 109.5 & 107.9 \\
5 & 18.8 & 15.8 & 109.5 & 108.3 \\
6 & 18.8 & 16.9 & 109.5 & 107.6 \\
7 & 18.8 & 18.0 & 109.5 & 109.0 \\
8 & 18.8 & 17.8 & 109.5 & 105.4 \\
9 & 18.8 & 16.9 & 109.5 & 100.2 \\
Atap & 18.8 & 15.0 & 109.5 & 99.8 \\
\hline
\end{tabular}

\section{Evaluasi Struktur Dinding Geser}

Dinding geser (shear wall) merupakan salah satu struktur tambahan yang berfungsi untuk menahan beban aksial seperti hal nya pada struktur kolom. Dinding geser merupakan dinding yang memiliki tulangan di dalamnya. Dinding geser biasanya digunakan pada saat pembuatan lift. Berdasarkan hasil analisis aplikasi ETABS V16.1, dapat dilihat bahwa dinding geser yang menyusun lift tersebut aman dalam menahan beban yang ada, yang ditandai dengan tidak adanya warna merah pada dinding geser tersebut (overstress).

Dinding geser yang digunakan pada lift gedung hotel ini menggunakan mutu beton K-28 MPa. Tulangan yang digunakan pada lift ini adalah tulangan D-16 sebanyak 2 lapis. Dimensi lift ini meliputi tebal dinding geser sebesar 200 $\mathrm{mm}$, panjang dinding geser sebesar 5000 $\mathrm{mm}$, tinggi dinding geser sebesar 3300 $\mathrm{mm}$. Berdasarkan perhitungan manual, 
diperoleh gaya geser nominal dinding geser tersebut sebesar $8238.5 \mathrm{kN}$ sedangkan gaya geser ultimit yang dihasilkan oleh aplikasi ETABS V16.1 sebesar $8194.7 \mathrm{kN}$. Oleh karena itu, dinding geser yang telah dibangun di gedung hotel ini sudah sesuai dengan ketentuan perencanaan yang ada sehingga aman dalam menahan beban yang ada.

Tabel 10. Perbandingan Gaya Geser Nominal dan Ultimit Dinding Geser

\begin{tabular}{cc}
\hline \multicolumn{2}{c}{ Gaya Geser } \\
\hline Nominal $(\mathrm{kN})$ & Ultimit $(\mathrm{kN})$ \\
8238.5 & 8194.7 \\
\hline
\end{tabular}

\section{KESIMPULAN}

Simpulan yang dapat diambil dari penelitian ini adalah :

1. Berdasakan hasil analisis aplikasi ETABS V16.1, jumlah tulangan hasil desain tidak berbeda jauh dengan kondisi eksistingnya sehingga jumlah tulangan telah sesuai dengan perencanaan yang ada.

2. Berdasarkan hasil analisis aplikasi ETABS V16.1, gaya dalam nominal yang ada di kolom, balok, plat lantai dan dinding geser lebih besar dibandingkan dengan gaya dalam ultimitnya sehingga kolom, balok, plat lantai dan dinding geser mampu untuk menahan beban gempa yang ada.

\section{DAFTAR PUSTAKA}

Badan Standardisasi Nasional. (2019). SNI 03-2847-2019 tentang Tata Cara Perhitungan Struktur Beton. Jakarta: Departemen Permukiman dan Prasarana Wilayah.

Badan Standardisasi Nasional. (2019). SNI 03-1726-2019 tentang Tata Cara Perencanaan Ketahanan Gempa untuk Struktur Bangunan
Gedung dan Non Gedung. Jakarta:

Badan Standardisasi Nasional.

Badan Standarisasi Nasional. (2013). SNI 03-1727-2013 tentang Beban Minimum untuk Perencanaan Bangunan Gedung dan Struktur Lain. Jakarta: Departemen Pekerjaan Umum.

Egan, \& Leo, E. (2018). Analisis Gaya dan Momen yang Terjadi di Sekitar Elemen Chord dan Balok Kolektor Akibat Gaya Gempa Pada Bangunan Bertingkat Tinggi. JMTS: Jurnal Mitra Teknik Sipil, 1(1), 271-280. https://doi.org/10.24912/jmts.v1i1 .2266

Fajar Meidiansyah, A., Yanuar Purwanto, M. J., \& Fauzan, M. (2014). Analisis Struktur Box Girder Jembatan Fly Over Rawa Buaya Sisi Barat Terhadap Gempa. Jurnal Teknik Sipil Dan Lingkungan, 1(1), 42-56. https://doi.org/10.29244/jsil.1.1.4 2-56

Ismail, M. (2014). Analisis Kinerja Struktur Atas Gedung 7 lantai Dengan Variasi Dimensi dan Lokasi Shearwall Studi Kasus Konsep Kondominium Hotel. Jurnal Teknik Sipil Dan Lingkungan, 2(1), 196-208.

Jasman, F. B. (2015). Desain Dan Pemodelan Upper Structure Proyek Pembangunan Perkantoran 7 Lantai Kabupaten Tangerang, Banten [Bogor Agricultral University (IPB)]. http://repository.ipb.ac.id/handle/ $123456789 / 78180$ 